\title{
ANALISIS PEMANIS NATRIUM SIKLAMAT PADA MINUMAN JAJANAN YANG DIJUAL DI DAERAH SEKITAR KAMPUS UNIVERSITAS SAM RATULANGI MANADO
}

\author{
Triska M. Manoppo ${ }^{1)}$, Sri Sudewi ${ }^{1)}$, Defny S. Wewengkang ${ }^{1)}$ \\ ${ }^{1)}$ Program Studi Farmasi FMIPA UNSRAT Manado, 95115
}

\begin{abstract}
Snack beverages like ice cendol, young coconut ice and mixed ice are snacks that are in great demand by students in the campus area. The sweet taste makes it an example of a product that uses artificial sweetener. Sodium cyclamate is an artificial sweetener whose use is permissible, but may not exceed the limits of its use. This study aims to determine the presence of sodium cyclamate and its level in snack food sold in the Sam Ratulangi University campus area of Manado. The identification of sodium cyclamate was carried out using the TLC method by comparing the Rf value from the standard and the sample. Method validation was done by using parameters such as linearity, detection limits and quantitation, accuracy, and precision limits. The linear relationship between concentration and absorbance was indicated by the equation of ; $y=0.0029 x-1.9155$ with a value of $r^{2}=0.9989$ so that the correlation between absorbance and the concentration of cyclamate standard could be very strong. The detection limit obtained 3.724 ppm and the quantity limit was 12.414 ppm. Accuracy test is stated with percent recovery of $102.659 \%$. Precision values are expressed with RSD of $1.1 \%$ and $2.0 \%$ which means good precision. The results showed that the quantitative analysis of sodium cyclamate content in the sample was not detected while in the quantitative analysis the samples were detected to contain sodium cyclamate but below the maximum level of use that is $1 \mathrm{~g} / \mathrm{Kg}$ food and beverage ingredients so it was save for consumption.
\end{abstract}

Keywords: Snacks, Sodium Cyclamate, Thin Layer Chromatography, Spectrophotometry UV-Vis, Manado.

\begin{abstract}
ABSTRAK
Minuman jajanan seperti es cendol, es kelapa muda dan es campur merupakan minuman jajanan yang banyak diminati mahasiswa di daerah kampus. Rasanya yang manis menjadikannya salah satu contoh produk yang menggunakan pemanis buatan. Natrium siklamat adalah pemanis buatan yang penggunaannya dibolehkan, namun tidak boleh melebihi batas penggunaannya. Penelitian ini bertujuan untuk mengetahui keberadaan natrium siklamat dan kadar natrium siklamat dalam minuman jajanan yang dijual di daerah kampus Universitas Sam Ratulangi Manado. Identifikasi natrium siklamat dilakukan dengan menggunakan metode KLT dengan mebandingkan harga Rf dari baku dan sampel. Validasi metode dilakukan dengan menggunakan parameter-parameter seperti linearitas, batas deteksi dan batas kuantitasi, akurasi, dan presisi. Hubungan linier antara konsentrasi dengan absorbansi ditunjukkan dengan persamaan $\mathrm{y}=0,0029 \mathrm{x}-1,9155$ dengan nilai $\mathrm{r}=0,9989$ sehingga dapat dikatakan korelasi antara absorbansi dan konsentrasi standar siklamat sangat kuat. Batas deteksi yang didapat 3,724 ppm dan batas kuantitas adalah $12,414 \mathrm{ppm}$. Uji akurasi dinyatakan dengan persen perolehan kembali sebesar 102,659\%. Nilai presisi dinyatakan dengan RSD sebesar $1,1 \%$ dan $2 \%$ yang berarti presisi baik. Hasil penelitian menunjukkan bahwa pada analisis kualitatif kandungan natrium siklamat pada sampel tidak terdeteksi sedangkan pada analisis kuantitatif sampel terdeteksi mengandung natrium siklamat tetapi dibawah kadar maksimum penggunaannya yaitu $1 \mathrm{~g} / \mathrm{Kg}$ bahan makanan dan minuman sehingga aman untuk dikonsumsi.
\end{abstract}

Kata Kunci : Minuman Jajanan, Natrium Siklamat, Kromatografi Lapis Tipis, Spektrofotometri UVVis,Manado. 


\section{PENDAHULUAN}

Minuman jajanan adalah minuman yang tidak mengandung alkohol, merupakan minuman olahan dalam bentuk bubuk atau cair yang mengandung bahanbahan tambahan lainnya baik alami maupun sintetik yang dikemas dalam kemasan siap untuk di konsumsi. Minumam jajanan yang dijual di berbagai tempat banyak ragamnya, ada minuman ringan, es sirup, es cendol, limun dan masih banyak lainnya. Minuman jajanan yang aman ialah minuman minuman jajanan yang bebas dari bahaya fisika, bahaya kimia dan bahaya biologis (Cahyadi, 2009).

Bahan Tambahan Makanan atau Bahan Tambahan Pangan adalah bahan yang ditambahkan kedalam makanan dan minuman untuk mempengaruhi sifat ataupun bentuk dari makanan dan minuman (Yuliarti, 2007). Pemanis merupakan senyawa kimia yang banyak ditambahkan dan digunakan dalam berbagai produk. Pemanis berfungsi untuk meningkatkan cita rasa dan aroma, memperbaiki sifat-sifat kimia sekaligus nilai gizinya diperlukan oleh tubuh dan bahkan digunakan sebagai pengganti bahan pemanis utama. Bahan pemanis dapat digolongkan menjadi dua bagian yaitu pemanis alami dan pemanis sintetis atau buatan (Widana, 2014).

Salah satu sarana atau tempat distribusi minuman jajanan adalah di daerah sekitar kampus, dimana mahasiswa menjadi sasaran utama penjualan minuman tersebut. Rasanya yang enak, manis, dan segar serta penampilannya yang menarik, menjadikan minuman jajanan banyak disukai oleh mahasiswa. Rasanya yang manis menjadikannya salah satu contoh produk yang menggunakan pemanis sintetik atau pemanis buatan.

Penggunaan pemanis buatan perlu diwaspadai karena dalam takaran yang berlebih dapat menimbulkan efek samping yang merugikan kesehatan manusia (Yusuf dan Nisma, 2013). Hasil metabolisme dalam tubuh dari siklamat adalah sikloheksilamin yang bersifat promotor karsinogenik, sehingga penggunaannya berbahaya bagi kesehatan manusia. Ekskresi siklamat dalam urin dapat merangsang tumor dan mampu menyebabkan antrofi yaitu pengecilan testikular dan kromosom. Pengkonsumsian siklamat dalam jumlah lebih akan mengakibatkan kanker kandung kemih. Selain itu, akan menyebabkan tumor paru, hati dan limfa (Wati, 2004). Pemakaian siklamat masih diperbolehkan, namun dengan batas maksimum yang telah ditentukan. Menurut Peraturan Menteri Kesehatan RI No. 722/Menkes/Per/IX/1988, kadar maksimum asam siklamat yang diperbolehkan dalam makanan dan minuman yang berkalori rendah dan untuk masyarakat umum adalah $1 \mathrm{gr} / \mathrm{kg}$ bahan makanan dan minuman, menurut WHO (World Health Organization) batas konsumsi harian siklamat yang aman adalah $11 \mathrm{mg} / \mathrm{Kg}$ berat badan.

Berdasarkan hal-hal diatas, maka perlu dilakukan analisis kadar pemanis pada produk minuman jajanan yang dijual di daerah sekitar kampus Universitas Sam Ratulangi Manado.

\section{METODOLOGI PENELITIAN}

Alat

Alat-alat yang digunakan yaitu seperangkat alat Spektrofotometri UV-Vis (Shimadzu), plat KLT Kieselgel G, 
Komputer pengolah data (Acer Aspire ES 11), alat-alat gelas (pyrex), corong pisah (pyrex), timbangan analitik (KERN AC 22 $-4 \mathrm{M})$, dan lemari pendingin (Samsung).

\section{Bahan}

Bahan-bahan yang digunakan yaitu natrium siklamat, aquades, natrium sulfat nahidrat, etanol, amonia, pereaksi $\mathrm{AgNO}_{3}$, $\mathrm{NaOH} 10 \mathrm{M}, \mathrm{NaOH}$ 0,5 M, $\mathrm{H}_{2} \mathrm{SO}_{4}$ Pekat, $\mathrm{H}_{2} \mathrm{SO}_{4} 30 \%, \mathrm{H}_{2} \mathrm{SO}_{4} 10 \%$, sikloheksan, Natrium hipoklorit $1 \%$, etil asetat dan sampel minuman jajanan yang diperoleh dari pedagang di daerah sekitar kampus Universitas Sam Ratulangi Manado.

\section{Prosedur Kerja}

\section{Pengambilan Sampel}

Sampel minuman jajanan diambil dari penjual di daerah sekitar kampus Universitas Sam Ratulangi Manado. Sampel diambil pada enam penjual berbeda, dimana tiap penjual diambil satu jenis minuman jajanan.

2. Larutan Stok (Hadju dkk., 2012)

Ditimbang sejumlah $50 \mathrm{mg}$ natrium siklamat, kemudian dimasukkan ke dalam labu $50 \mathrm{~mL}$ dan dilarutkan dengan aquades sampai tanda tera.

3. Analisis Kualitatif Siklamat dengan Metode KLT

\section{a. Pembuatan Larutan Baku} (Pembanding Natrium Siklamat)

Seberat 0,0100 gram natrium diklamat ditambahkan dengan etanol $50 \%$ sebanyak $10 \mathrm{~mL}$ dilarutkan hingga homogen, kemudian di uapkan hingga $2 \mathrm{~mL}$.

\section{b. Pembuatan Larutan Sampel}

Sebanyak $100 \mathrm{~mL}$ sampel diasamkan dengan $10 \mathrm{~mL}$ asam sulfat $10 \%$ lalu diekstraksi dengan $50 \mathrm{~mL}$ etil asetat dalam corong pisah. Lapisan etil asetat disaring melalui natrium sulfat anhidrat untuk menghilangkan sisa air, lalu ekstrak etil asetat ini diuapkan hingga tersisa $2 \mathrm{~mL}$.

c. Pembuatan Pembanding dan Sampel

Masing-masing sebanyak $5 \mu \mathrm{L}$ larutan sampel (hasil penguapan etil asetat) dan larutan baku di totolkan pada lempeng fase diam Kieselgel $\mathrm{G}$ dengan jarak penotolan $1 \mathrm{~cm}$ dari tepi lempeng. Lempeng direndam dalam bejana kromatografi (chamber) yang telah jenuh dengan uap fase gerak (etanol:amonia dengn perbandingan 9:1) hingga mencapai jarak $8 \mathrm{~cm}$ dari tempat penotolan. Lempeng disemprot dengan pereaksi $\mathrm{AgNO}_{3}$. Setelah disemprot, lempeng dikeringkan dan dibiarkan di bawah sinar UV selama 1 menit. Adanya warna putih pada bercak sampel yang mempunyai harga $\mathrm{Rf}$ yang sama dengan bercak baku menunjukkan adanya siklamat.

$\mathrm{Rf}=\frac{\text { Jarak yang ditempuh oleh sampel }}{\text { Jarak yang ditempuh oleh pelarut }}$

\section{Penentuan Panjang Gelombang Maksimum ( $\lambda$ maks)}

Dari larutan baku siklamat 1000 ppm, diambil $40 \mathrm{~mL}$ lalu di encerkan dengan aquades sampai volume $50 \mathrm{~mL}$ hingga diperoleh konsentrasi 800 ppm. Larutan dengan konsentrasi 800 ppm tersebut dikocok sehingga homogen dan dimasukkan kedalam kuvet kemudian dibaca absorbansinya pada panjang gelombang ultra violet yaitu antara panjang gelombang $200-400 \mathrm{~nm}$. 


\section{Operating Time}

Dari larutan baku 1000 ppm diencerkan menjadi konsentrasi 800 ppm dengan cara diambil $40 \mathrm{~mL}$ larutan 1000 ppm, tambahkan aquades sampai volume $50 \mathrm{~mL}$ kocok hingga homogen lalu dibaca absorbansinya sampai hasil absorbansi yang diperoleh relatif konstan dengan rentan waktu 0-30 menit.

6. Validasi Siklamat dengan Metode Spektrofotometri UV-Vis

a. Larutan Blanko (Padmaningrum dan Marwati, 2015).

Dipipet $50 \mathrm{~mL}$ air, dimasukkan ke dalam corong pisah pertama, ditambahkan 2,5 $\mathrm{mL} \mathrm{H}_{2} \mathrm{SO}_{4}$ pekat dan didinginkan, setelah dingin ditambahkan $50 \mathrm{~mL}$ etil asetat dikocok selama 2 menit. Lapisan bawah dibuang. Lapisan etil asetat atau lapisan atas dikocok 3 kali setiap kali dengan $15 \mathrm{~mL}$ air, lapisan air dikumpulkan dan dimasukkan ke dalam corong pisah kedua, ditambahkan $1 \mathrm{~mL} \mathrm{NaOH} 10 \mathrm{M}$ dan $5 \mathrm{~mL}$ sikloheksan, dikocok selama 1 menit. Dipisahkan lapisan air dan dimasukkan ke dalam corong pisah ketiga, ditambahkan 2,5 $\mathrm{mL} \mathrm{H}_{2} \mathrm{SO}_{4}$ $30 \%$, $5 \mathrm{~mL}$ sikloheksan, $5 \mathrm{~mL}$ larutan hipoklorit yang mengandung $1 \%$ klor bebas dan dikocok selama 2 menit. Lapisan sikoheksan akan berwarna kuning kehijauan, bila tidak berwarna ditambahkan lagi larutan hipoklorit lebih kurang $5 \mathrm{~mL}$. Dibuang lapisan bawah, lapisan sikloheksan dibilas dengan $25 \mathrm{~mL}$ $\mathrm{NaOH} \quad 0,5$ M. Kemudian lapisan bawah dibuang dan dibilas lagi dengan $25 \mathrm{~mL}$ aquades. Lapisan atas atau lapisan sikloheksan diambil. b. Kurva Standar (Padmaningrum dan Marwati, 2015).

Empat buah labu takar $50 \mathrm{~mL}$ masing-masing diisi dengan larutan standar siklamat $1000 \mathrm{pm}$ dengan variasi volume : 37,5; 40; 42,5; dan $45 \mathrm{~mL}$ sehingga konsentrasi siklamat dalam larutan blanko adalah 750; 800; 850; dan 900 ppm, dan diencerkan sampai tanda batas. Larutan tersebut di pindahkan kedalam corong pemisah, ditambah 2,5 $\mathrm{mL} \mathrm{H}_{2} \mathrm{SO}_{4}$ pekat, didinginkan. Setelah dingin, campuran ditambahkan $50 \mathrm{~mL}$ etil asetat dan dikocok selama 2 menit. Lapisan etil asetat dipisahkan dan dimasukkan ke dalam corong pemisah kedua, dikocok 3 kali, setiap kali dengan 15 $\mathrm{mL}$ aquades. Lapisan air dikumpulkan dan dimasukkan ke dalam corong pemisah ketiga, ditambah $1 \mathrm{~mL}$ larutan $\mathrm{NaOH} 10 \mathrm{M}$, $5 \mathrm{~mL}$ sikloheksan dan dikocok selama 1 menit.

Lapisan air dikumpulkan dan dimasukkan ke dalam corong pemisah keempat, ditambahkan 2,5 $\mathrm{mL} \mathrm{H}_{2} \mathrm{SO}_{4} 30 \%, 5 \mathrm{~mL}$ sikloheksan dan $5 \mathrm{~mL}$ larutan Na-hipoklorit $1 \%$. Lapisan sikloheksan akan berwarna kuning kehijauan, bila tidak berwarna ditambahkan $5 \mathrm{~mL}$ larutan Na-hipoklorit $1 \%$ Lapisan sikloheksan dicuci dengan $25 \mathrm{~mL}$ $\mathrm{NaOH} 0,5 \mathrm{M}$, dikocok selama 1 menit dan lapisan bawah dibuang. Lapisan sikloheksan dikocok dengan $25 \mathrm{~mL}$ aquades, diambil lapisan sikloheksan dan lapisan air dibuang. Lapisan sikloheksan diukur serapannya pada panjang gelombang maksimum terpilih dan larutan 
blanko sebagai pembanding. Kurva standar dibuat antara konsentrasi terhadap serapan sehingga diperoleh persamaan regresi yang dipergunakan untuk perhitungan pada analisis selanjutnya.

\section{c. Uji Linearitas}

Uji linearitas ditentukan melalui persamaan regresi linier $\mathrm{Y}=$ $\mathrm{ax}+\mathrm{b}$ dan nilai $\mathrm{r}^{2}$ dari 4 kali pengulangan pengukuran absorbansi kurva standar. Korelasi dinyatakan sangat kuat jika nilai $r$ yang diperoleh di atas 0,9 tetapi kurang dari 1,0 sesuai dengan kriteria.

\section{d. Uji Batas Deteksi dan Batas} Kuantitasi

Penentuan Batas Deteksi / Limit of Detection (LOD) dan Batas Kuantitasi / Limit Of Quantitation (LOQ) dihitung melalui persamaan garis linier dari kurva kalibrasi, dengan rumus :

$$
\begin{gathered}
\mathrm{SB}=\frac{\sqrt{\sum\left(y-y^{\prime}\right)^{2}}}{n-2} \\
\mathrm{LOD}=\frac{3 \times S b}{S} \\
\mathrm{LOQ}=\frac{10 \times S b}{S}
\end{gathered}
$$

\section{e. Uji Akurasi}

Penentuan akurasi dilakukan dengan metode penambahan standar. Pada larutan siklamat yang telah diketahui konsentrasinya ditambahkan larutan standar siklamat 750 dan 850 ppm. Kemudian larutan tersebut dibaca absorbansinya menggunakan spektrofotometer UV-Vis dengan 3 kali pengulangan. Akurasi dipresentasikan sebagai nilai perolehan kembali. Nilai perolehan kembali dihitung dengan cara membandingkan konsentrasi yang diperoleh dan konsentrasi sebenarnya dan dikalikan $100 \%$.

$\%$ Perolehan kembali $=\frac{\text { Konsentrasi yang diperoleh }}{\text { Konsentrasi sebenarnya }} \times 100 \%$

\section{f. Uji Presisi}

Selisih dari nilai perolehan kembali rata-rata ketiga konsentrasi natrium siklamat dikurangi nilai perolehan kembali rata-rata per konsentrasi. Kemudian dihitung nilai simpangan baku (standar deviasi / SD) dan nilai simpangan baku relatif atau koefisien variasi (KV) masingmasing konsentrasi. Standar deviasi dan koevisien variasi dihitung dengan mengikuti rumus :

$$
\begin{aligned}
\mathrm{SD} & =\sqrt{\frac{\sum(x i-\bar{x})^{2}}{n-1}} \\
\% \mathrm{RSD} & =\frac{S D}{x} \times 100 \%
\end{aligned}
$$

\section{Analisis Kuantitatif (Hadju dkk, 2012)}

Diambil sejumlah $50 \mathrm{~mL}$ sampel, dimasukkan kedalam corong pisah pertama, ditambahkan 2,5 mL $\mathrm{H}_{2} \mathrm{SO}_{4}$ pekat. Setelah dingin, ditambahkan $50 \mathrm{~mL}$ etil asetat, dikocok selama 2 menit. Dipisahkan lapisan etil asetat dan ambil $40 \mathrm{~mL}$, bagian yang jernih, kemudian dimasukkan kedalam corong pisah kedua. Dikocok 3 kali dengan $15 \mathrm{~mL}$ air, dikumpulkan lapisan air, dimasukkan ke dalam corong pisak ketiga, ditambahkan $1 \mathrm{~mL} \mathrm{NaOH} 10 \mathrm{M}$, $5 \mathrm{~mL}$ sikloheksan dan dikocok selama 1 menit.

Dipisahkan lapisan air dan dimasukkan ke dalam corong pisah keempat, ditambahkan 2,5 $\mathrm{mL} \mathrm{H}_{2} \mathrm{SO}_{4}$ $30 \%$, $5 \mathrm{~mL}$ sikloheksan, $5 \mathrm{~mL}$ larutan Na-hipoklorit yang mengandung $1 \%$ klor bebas dan dikocok selama 2 menit. Lapisan sikloheksan akan berwarna 
kuning kehijauan, bila tidak berwarna ditambahkan lagi larutan Na-hipoklorit lebih kurang $5 \mathrm{~mL}$. Lapisan air dibuang, lapisan sikloheksan ditambahkan $25 \mathrm{~mL}$ $\mathrm{NaOH}$ 0,5 M, dikocok dipisahkan dan diambil lapisan bawah. Lapisan bawah dibuang, kemudian dibilas dengan 25 $\mathrm{mL}$ aquades. Lapisan atas dibaca absorbansinya.

\section{HASIL DAN PEMBAHASAN}

\section{Pengambilan Sampel}

Pada penelitian ini, sampel yang digunakan yaitu minuman jajanan yang dijual di daerah sekitar kampus Universitas Sam Ratulangi Manado. Pengambilan sampel dilakukan berdasarkan metode purposive sampling yaitu teknik pengambilan sampel berdasarkan pertimbangan tertentu yakni pertimbangan sesuai dengan kriteria yang ditetapkan untuk tujuan penelitian agar sampel yang di ambil representatif (mewakili). Pengaruh sampel pada penelitian ini yaitu sampel merupakan minuman jajanan yang menggunakan pemanis.

\section{Analisis Kualitatif Natrium Siklamat} dengan Metode KLT

Analisis kualitatif pada penelitian ini menggunakan metode KLT (Kromatografi Lapis Tipis). Analisis kualitatif digunakan untuk mengetahui adanya kandungan pemanis natrium siklamat dengan membandingkan harga Rf dari bercak baku dan bercak sampel. Hasil dari analisis kualitatif menggunakan metode KLT (Kromatografi Lapis Tipis) dapat dilihat pada Tabel 1.
Tabel 1. Hasil analisis kualitatif pemanis natrium siklamat menggunakan metode KLT (Kromatografi Lapis Tipis)

\begin{tabular}{cccccc}
\hline \multirow{3}{*}{ Sampel } & \multicolumn{2}{c}{ Jarak Bercak $(\mathrm{cm})$} & & \\
\cline { 2 - 3 } & $\begin{array}{c}\text { Jarak } \\
\text { Sampel }\end{array}$ & $\begin{array}{c}\text { Jarak } \\
\text { Pelarut }\end{array}$ & & Ket \\
\hline Baku & $3,7 \mathrm{~cm}$ & $8 \mathrm{~cm}$ & & 0,463 & + \\
A & $4,2 \mathrm{~cm}$ & $8 \mathrm{~cm}$ & 0,525 & - \\
B & $6,4 \mathrm{~cm}$ & $8 \mathrm{~cm}$ & 0,800 & - \\
C & $5,2 \mathrm{~cm}$ & $8 \mathrm{~cm}$ & 0,650 & - \\
D & $5,8 \mathrm{~cm}$ & $8 \mathrm{~cm}$ & 0,725 & - \\
E & $6,1 \mathrm{~cm}$ & $8 \mathrm{~cm}$ & 0,763 & - \\
F & $4,6 \mathrm{~cm}$ & $8 \mathrm{~cm}$ & 0,575 & - \\
\hline \multicolumn{3}{c}{ Berdasarkan } & hasil & \multicolumn{2}{c}{ analisis }
\end{tabular}
kualitatif pada tabel 1 diatas, dapat dilihat bahwa keenam sampel negatif mengandung pemanis natrium siklamat. Hal ini dapat dilihat bahwa harga Rf dari baku yaitu 0,463 sedangkan harga Rf dari sampel A, B, C, D, E, dan F yaitu $0,525,0,800,0,650,0,725,0,763$ dan 0,575 .

3. Penentuan Panjang Gelombang Maksimum Natrium Siklamat $(\lambda$ maks)

Penentuan panjang gelombang maksimum ( $\lambda$ maks) ini digunakan untuk mengetahui pada daerah serapan berapa zat dibaca oleh spektrofotometri UV secara optimum. Hasil penentuan panjang gelombang natrium siklamat dapat dilihat pada Gambar 1.

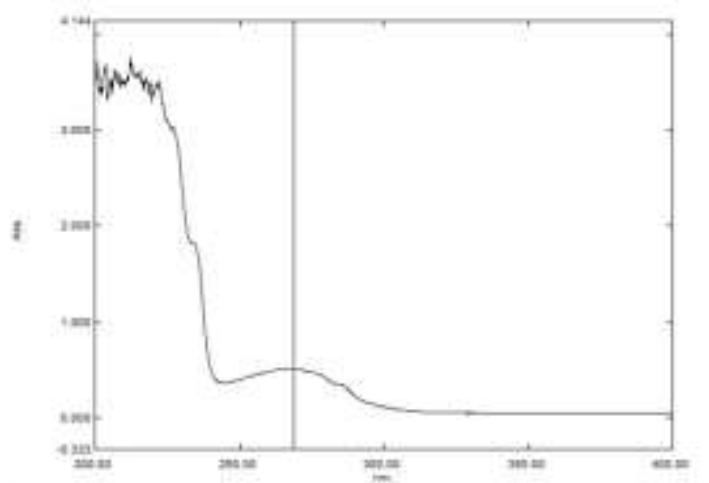

Gambar 1. Kurva absorbansi natrium siklamat dalam konsentrasi $800 \quad$ ppm dengan pelarut aquades, 
pada panjang gelombang 200-400 nm.

Berdasarkan hasil kurva absorbansi diatas, didapat panjang gelombang maksimum natrium siklamat yaitu $268 \mathrm{~nm}$. Hasil ini masih dalam kisaran daerah serapan optimum natrium siklamat yaitu 220-300 $\mathrm{nm}$. Sehingga dapat dikatakan hasil dari pengukuran panjang gelombang maksimum ini memenuhi syarat penggunaannya untuk analisis.

\section{Operating Time}

Setelah didapat panjang gelombang maksimum dari natrium siklamat maka langkah selanjutnya adalah menentukan operating time. Dalam rentang waktu 0 - 30 meni, sejak menit pertama sampai menit ke tiga puluh menunjukkan waktu pengukuran yang stabil dengan hasil absorbansi 0,48 . Hal ini menunjukkan bahwa berdasarkan kestabilan waktu yang optimal untuk pembacaan absorbansi adalah dimulai dari menit pertama sampai menit ke tiga puluh.

\section{Validasi Metode Analisis}

\section{a. Pembuatan Kurva Baku}

Untuk melakukan validasi metode analisis maka hal pertama yang dilakukan adalah membuat kurva baku. Kurva baku diperoleh dengan cara membuat 4 seri konsentrasi yaitu 750, 800, 850, dan 900 ppm dari larutan standar 1000 ppm. Hasil absorbansi dari ke empat seri konsentrasi dapat dilihat pada Tabel 2.
Tabel 2. Data hasil kurva baku natrium siklamat

\begin{tabular}{cc}
\hline Konsentrasi & Absorbansi \\
\hline $750 \mathrm{ppm}$ & 0,221 \\
$800 \mathrm{ppm}$ & 0,370 \\
$850 \mathrm{ppm}$ & 0,499 \\
$900 \mathrm{ppm}$ & 0,653 \\
\hline
\end{tabular}

\section{b. Uji Linearitas}

Berdasarkan hasil dari kurva baku maka kita dapat menentukan uji linearitas yaitu dengan melihat nilai koefisien korelasi (r) pada persamaan $\mathrm{y}=\mathrm{ax}+\mathrm{b}$. Hasil kurva kalibrasi dan persamaan regresi liniear dapat dilihat pada Gambar 2.

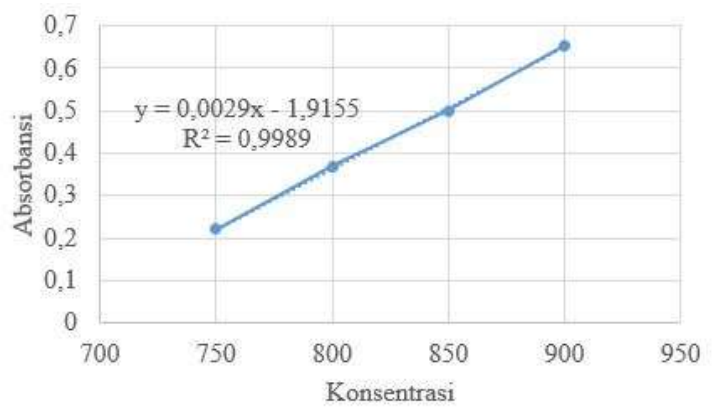

Gambar 2. Grafik kurva kalibrasi natrium siklamat

Berdasarkan gambar diatas dapat dilihat bahwa persamaan regresi liniear yang diperoleh yaitu y $=0,0029 x-1,9155$. Dari persamaan tersebut di dapat koefisien korelasi yaitu $r^{2}=0,9989$. Koefisien korelasi inilah yang digunakan untuk mengetahui linearitas suatu metode analisis. Menurut Sharger (1985) nilai koefisien korelasi yang mendekati 1 menyatakan hubungan linear antara konsentrasi dengan serapan yang dihasilkan sangat baik.

c. Uji Batas Deteksi (LOD) dan Batas Kuantifikasi (LOQ)

Setelah diperoleh data dari konsentrasi tiap analit yang memberikan absorbansi berbeda maka selanjutnya data yang 
diperoleh diolah untuk menentukan batas deteksi (LOD) dan batas kuantitas (LOQ). Dalam penelitian ini batas deteksi (LOD) yang diperoleh adalah 3,724 ppm sedangkan untuk batas kuantitas (LOQ) adalah 12,414 ppm.

\section{d. Uji Akurasi (Ketepatan)}

Uji akurasi dalam penelitian ini menggunakan metode panambahan baku yaitu dengan membuat larutan konsentrasi 750 ppm dan 850 ppm yang kemudian masing-masing konsentrasi dibaca absorbansinya sebanyak 3 kali pengulangan. Setelah absorbansi didapat kemudian dilakukan perhitungan, diperoleh hasil rata-rata persen perolehan kembali yaitu sebesar 102,659 \%. Persen perolehan kembali ini dapat diterima karena memenuhi syarat akurasi yaitu pada rentang rata-rata persen perolehan kembali 80-110\% (WHO, 1992). Data hasil uji akurasi (ketepatan) dapat dilihat pada Tabel 3.

Tabel 3. Data Hasil Uji Akurasi Siklamat

\begin{tabular}{cc}
\hline $\begin{array}{c}\text { Konsentrasi } \\
(\mathrm{ppm})\end{array}$ & $\begin{array}{c}\text { \% Perolehan } \\
\text { kembali }\end{array}$ \\
\hline 750 & $102,782 \%$ \\
850 & $102,590 \%$ \\
Rata-rata & $102,659 \%$ \\
\hline
\end{tabular}

\section{e. Uji Presisi (Ketelitian)}

Dalam penelitian ini presisi ditentukan dengan melakukan pengulangan sebanyak 3 kali pada konsentrasi $750 \mathrm{ppm}$ dan $850 \mathrm{ppm}$. Presisi diukur sebagai simpangan baku atau simpangan baku relatif (koefisien variasi). Simpangan baku (SD) dan koefisien variasi (KV) digunakan sebagai parameter pada metode ini yang dapat menghasilkan nilai rata-rata yang sangat dekat dengan nilai sebenarnya.

Hasil perhitungan simpangan baku (SD) data yang diperoleh dari 3 kali pengulangan pada penelitian ini yaitu untuk kosentrasi 750 ppm diperoleh nilai simpangan baku (SD) yaitu sebesar 8,613 dan simpangan baku relatif (koefisien variasi) sebesar $1,1 \%$. Sedangkan untuk konsentrasi 850 ppm diperoleh nilai simpangan baku (SD) yaitu 17,506 dengan nilai simpangan baku relatif (koefisien variasi) sebesar $2 \%$. Menurut Harmita (2004) syarat uji presisi yang baik yaitu dengan nilai koefisien variasi $(\mathrm{KV}) \leq 2 \%$. Berdasarkan hal tersebut maka dapat disimpulkan bahwa pengujian presisi dengan metode spektrofotometri yang digunakan adalah baik. Data hasil uji presisi dapat dilihat pada Tabel 4.

Tabel 4. Data Hasil Uji Presisi Siklamat

\begin{tabular}{cccccc}
\hline $\begin{array}{c}\text { Konse } \\
\text { ntrasi } \\
\text { (ppm) }\end{array}$ & $\begin{array}{c}\text { Absor } \\
\text { bansi }\end{array}$ & $x_{i}$ & $\bar{x}$ & SD & $\begin{array}{c}\text { RS } \\
(\%)\end{array}$ \\
& & & & & \\
& 0,292 & 761, & & & \\
750 & 0,340 & 777, & 770, & 8,61 & 1,1 \\
& & 759 & 863 & 3 & $\%$ \\
& 0,328 & 773, & & & \\
& & 621 & & & \\
& 0,572 & 857, & & & \\
& & 759 & & & \\
& 0,598 & 866, & 872, & 17,5 & $2 \%$ \\
& & 724 & 012 & 06 & \\
& 0,670 & 891, & & & \\
\hline
\end{tabular}

\section{Analisis Kuantitatif}

Analisis kuantitatif merupakan langkah selanjutnya untuk pengujian suatu sampel, dimana tujuannya untuk mengetahui berapa kadar dari sampel uji tersebut. Data analisis kuantitatif dapat dilihat pada Tabel 5. 
Tabel 5. Kadar Natrium Siklamat Pada

\begin{tabular}{|c|c|c|c|c|c|c|}
\hline \multicolumn{6}{|c|}{ Sampel } & \\
\hline $\begin{array}{c}\text { Sam } \\
\text { pel }\end{array}$ & $\begin{array}{l}\text { A } \\
\text { bs }\end{array}$ & $\begin{array}{c}\text { Kad } \\
\text { ar } \\
\text { Natr } \\
\text { ium } \\
\text { Sikl } \\
\text { amat } \\
\text { (pp } \\
\text { m) }\end{array}$ & $\begin{array}{l}\text { Bata } \\
\text { s } \\
\text { Dete } \\
\text { ksi } \\
\text { (pp } \\
\text { m) }\end{array}$ & $\begin{array}{c}\text { Kadar } \\
\text { Natriu } \\
\text { m } \\
\text { Sikla } \\
\text { mat } \\
(\mathrm{g} / \mathrm{Kg})\end{array}$ & $\begin{array}{c}\text { Kadar } \\
\text { Maksi } \\
\text { mum } \\
\text { Sikla } \\
\text { mat } \\
(\mathrm{g} / \mathrm{Kg})\end{array}$ & $\begin{array}{l}K \\
\mathrm{e} \\
\mathrm{t}\end{array}$ \\
\hline A & $\begin{array}{c}0 \\
13 \\
9\end{array}$ & $\begin{array}{l}708 \\
448\end{array}$ & & $\begin{array}{c}0,000 \\
7\end{array}$ & & + \\
\hline $\mathrm{C}$ & $\begin{array}{c}0, \\
24 \\
2\end{array}$ & $\begin{array}{l}743 \\
966\end{array}$ & $\begin{array}{c}3,72 \\
4\end{array}$ & $\begin{array}{c}0,000 \\
7\end{array}$ & 1 & + \\
\hline $\mathrm{F}$ & $\begin{array}{c}0, \\
17 \\
3\end{array}$ & $\begin{array}{c}720 \\
172\end{array}$ & & $\begin{array}{c}0,000 \\
7\end{array}$ & & + \\
\hline
\end{tabular}

Berdasarkan data pada Tabel 5,

ketiga sampel yang di uji menunjukkan nilai kadar natrium siklamat diatas nilai batas deteksi (LOD) sehingga dapat dikatakan bahwa ketiga sampel positif mengandung siklamat akan tetapi sampel aman untuk dikonsumsi karena kadar natrium siklamat didalam sampel dibawah kadar maksimum siklamat yang diperbolehkan dalam makanan dan minuman dan untuk masyarakat umum yaitu $1 \mathrm{~g} / \mathrm{Kg}$ bahan makanan dan minuman.

Apabila pada suatu sampel terdeteksi mengandung natrium siklamat, reaksi antara siklamat dengan larutan hipoklorit dalam suasana asam dan reaksi setelah penambahan $\mathrm{NaOH}$ dapat dilihat pada Gambar 3.

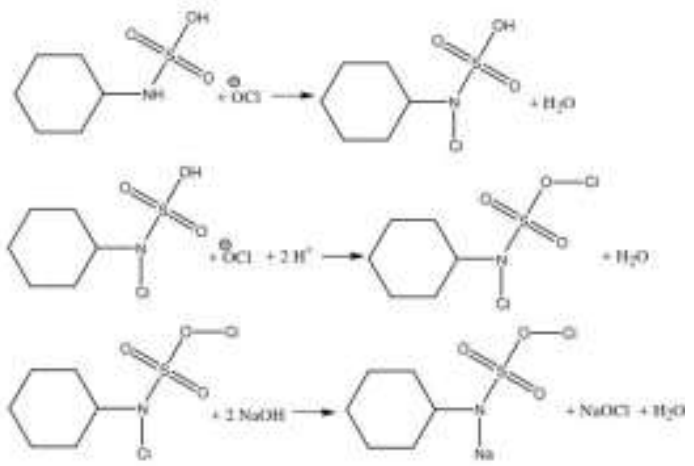

Gambar 3. Reaksi antara siklamat dengan hipoklorit dalam suasana asam dan reaksi setelah penambahan $\mathrm{NaOH}$ (Vogels, 1990).

\section{KESIMPULAN}

1. Berdasarkan hasil dari penelitian ini, pada analisis kualitatif menunjukkan bahwa sampel tidak mengandung pemanis natrium siklamat. Dimana harga Rf dari baku yaitu 0,463 sedangkan harga Rf dari sampel A, B, C, D, E, dan F yaitu 0,525, 0,800, $0,650,0,725,0,763$ dan 0,575.

2. Analisis kuantitatif dilakukan pada tiga sampel yang memiliki harga Rf mendekati harga Rf dari baku yaitu sampel A, C dan F. Hasil analisis kuantitatif pada penelitian ini menunjukkan bahwa ketiga sampel yang diuji menunjukkan nilai kadar natrium siklamat diatas nilai batas deteksi (LOD) sehingga dapat dikatakan bahwa ketiga sampel positif mengandung siklamat akan tetapi sampel aman untuk dikonsumsi karena kadar natrium siklamat didalam sampel dibawah kadar maksimum siklamat yang diperbolehkan dalam makanan dan minuman dan untuk masyarakat umum yaitu $1 \mathrm{~g} / \mathrm{Kg}$ bahan makanan dan minuman.

\section{SARAN}

1. Untuk peneliti selanjutnya agar melakukan analisis pemanis buatan jenis lain.

2. Untuk peneliti selanjutnya agar dapat menentukan kadar pemanis dengan menggunakan metode KCKT (Kromatografi Cair Kinerja Tinggi) 


\section{DAFTAR PUSTAKA}

Cahyadi, W. 2009. Analisis dan Aspek Kesehatan Bahan Tambahan Pangan. Edisi Kedua. Bumi Aksara, Jakarta.

Hadju, N. A., Tuju, T. D. J., Ludong, M. M., Langi, T. M. 2012. Analisis Zat Pemanis Buatan Pada Minuman Jajanan Yang Dijual Di Pasar Tradisional Kota Manado. [Skripsi]. Universitas Sam Ratulangi, Manado.

Harmita. 2004. Petunjuk Pelaksanaan Validasi Metode dan Cara Perhitungannya. Majalah Ilmu Kefarmasian. Vol 1 (3) : 117-135.

Yuliarti, N. 2007. Awas Bahaya Dibalik Lezatnya Makanan. ANDI, Yogyakarta.

Padmaningrum, R. T., Marwati, S. 2015. Validasi Metode Analisis Siklamat Secara Spektrofotometri dan Turbidimetri. Jurnal Sains Dasar. Vol 4 (1) : 23-29.

Permenkes. 1988. Peraturan Menteri Kesehatan Nomor 722 Tentang Bahan Tambahan Makanan. Sekertariat Negara, Jakarta.

Vogels. 1990. Analisis Anorganik Kualitatif Makro dan Semimikro. Kalman Media Pustaka, Jakarta.

Wati, H. H. 2004. Kadar Pemanis Buatan Pada Minuman Yang Dijual Di Sekolah Dasar Di Kecamatan Wonoyo Kabupaten Sidoarjo.
[Skripsi].

Universitas

Muhammadiyah, Malang.

WHO. 1992. The International Pharmacopeia Edisi Ke-empat. Electronic Version Geneva: World Health Organization.

Widana, G. A. B. 2014. Analisis Obat, Kosmetik, dan Makanan. Graha Ilmu, Yogyakarta.

Yusuf, Y. dan Nisma, F. 2013. Analisa Pemanis Buatan (Sakarin, Siklamat Dan Aspartam) Secara Kromatografi Lapis Tipis Pada Jamu Gendong Kunyit Asam Di Wilayah Kelapa Dua Wetan Jakarta Timur. [Skripsi]. Universitas Muhammadiyah Prof Dr. Hamka, Jakarta. 